\title{
A GUERRA É UMA ÓPERA E UMA GRANDE ÓPERA: AS CRÔNICAS DE MACHADO DE ASSIS E A QUESTÃO DO ORIENTE
}

\author{
Leonardo Francisco Soares \\ Universidade Federal de Uberlândia \\ Uberlândia (MG), Brasil
}

\begin{abstract}
Resumo: Tomando como ponto de partida as crônicas da série "História de quinze dias", de Machado de Assis, este estudo aborda um olhar particular sobre a guerra, em especial os conflitos que ocorrem nos Bálcãs no final da década de 1870, que transcende a dicção jornalística tradicional e materializa-se no limite tênue entre ficção e história. Com "graça dançarina", Machado de Assis mistura, em suas crônicas, reflexões de ordem variada, que vão do esboroar do Império Otomano ao surgimento de mulheres santas no nordeste. Essa relativização promovida pelo discurso machadiano é conduzida com cabal crueldade e ao mesmo tempo assume a face do humor, criando um estranhamento sistemático do discurso em relação aos fatos comentados.
\end{abstract}

Palavras-chave: literatura brasileira; crônica; guerra.

\section{War is an opera and a great opera: the chronicles of Machado de Assis and the Orient issue}

\begin{abstract}
Using Machado de Assis's short journalistic texts ("crônicas", chronicles), from the series "História de quinze dias", this article examines his peculiar way of considering war, specially the Balkan conflicts in the end of the 1870's. This peculiar way goes beyond the typical journalistic diction and dwells midway between fiction and history. With "dancing grace", Machado de Assis mingles, in his chronicles, various reflections, ranging from the decadence of the Ottoman Empire to the appearance of saintly women in the northeast of Brazil. This relativisation produced by Machado's speech is conducted with cruelty and humour, creating a continuous strangeness of the speech in relation to the referred facts.
\end{abstract}

Keywords: Brazilian literature; chronicle; war. 
Ao correr os olhos pelo grande número de estudos críticos e biográficos sobre Machado de Assis e sua obra, percebe-se que as crônicas jornalísticas do autor não foram alvo de atenção expressiva da crítica especializada. Pode-se conjecturar que, para além do fato de a crônica ser considerada por parte da crítica como um "gênero literário menor", ${ }^{1}$ tal desatenção à atividade de cronista tão intensamente praticada por Machado de Assis - inicia-se ainda na década de 1850, sendo recorrente até o limiar do século XX - deva-se, em primeiro lugar, a certo obstáculo que a leitura desses textos gera: a interlocução com o tempo, afinal, para dizer com Antonio Candido, "essa moderna filha de Cronos [...] não tem pretensões a durar, uma vez que é filha do jornal e da era da máquina, onde tudo acaba tão depressa". ${ }^{2}$ Mesmo que nem sempre sejam dependentes do contexto, como bem afirma John Gledson, ${ }^{3}$ essas crônicas têm o seu escopo ampliado e iluminado pelo conhecimento de fatos contemporâneos ao cronista e seus leitores imediatos.

Nesse ponto, surge um segundo problema: até o presente momento, as crônicas de Machado de Assis não foram publicadas de forma completa e organizada, levando-se em consideração o estabelecimento do texto e a necessidade de notas explicativas. As duas melhores e mais completas edições de suas crônicas eram as da W. M. Jackson, cuja primeira edição aparece em 1937, e aquela organizada por Raymundo Magalhães Júnior no final dos anos 1950. Se, por um lado, essas edições têm o mérito de dar a conhecer o Machado de Assis cronista, por outro, deixam a desejar, porque os textos não são efetivamente completos e pela falta de um trabalho crítico criterioso no estabelecimento e na apresentação dos mesmos. Tal estado de coisas dificulta ainda mais o trabalho do pesquisador que se volta para a crônica oitocentista. Todavia, recentemente, com as comemorações do centenário da morte de Machado de Assis, esse quadro, felizmente, começou a mudar, uma vez que um grupo significativo de estudiosos vêm trazendo à luz vários volumes das crônicas completas do autor, o que

\footnotetext{
${ }^{1}$ Por sua vez, em "A vida ao rés-do chão", Antonio Candido afirma: "[...] parece mesmo que a crônica é um gênero menor. // 'Graças a Deus', seria o caso de dizer, porque sendo assim ela fica perto de nós." Cf. CANDIDO, Antonio. A vida ao rés-do-chão. In: 1993. p. 23.

${ }^{2}$ Idem, p. 24.

${ }^{3}$ GLEDSON, John. A história contada em detalhes (Entrevista a Álvaro Kassab). Jornal da UNICAMP, n. 406, 25 a 31 ago. Campinas: 2008. p. 6-7.
} 
vem permitindo aos leitores o acesso ao texto original das peças literárias, estabelecido por especialistas e acompanhado de um amplo trabalho de pesquisa. ${ }^{4}$

Apesar de não atrair com tanta frequência o olhar mais apurado da crítica, muitas vezes ficando isolada do resto de sua obra, a produção jornalística de Machado de Assis já foi apontada, com justiça, como fundamental para o desenvolvimento da atividade literária do escritor. O primeiro a chamar atenção para a importância desses textos foi Mário de Alencar. Grande amigo e "discípulo" de Machado, Mário de Alencar preparou e organizou, ainda em 1910, uma edição da série "A Semana", publicada originalmente na Gazeta de Notícias entre 1892 e 1897. Nas suas palavras:

\begin{abstract}
A ideia de coligi-las nasceu do desejo de servir à memória do escritor, acrescentando-lhe às obras editadas em volume esta outra que tão bem caracteriza certas feições do seu engenho literário, e que seria de lamentar ficasse esquecida ou ignorada. Ao próprio autor lembrei e pedi que as reunisse em livro, e posto me objetasse às vezes com a dúvida sobre o valor desses escritos, salvo um ou outro além dos já publicados, nas Páginas recolhidas, não me pareceu que ficasse alheio ao pensamento de fazer a coleção. ${ }^{5}$
\end{abstract}

As "feições de engenho literário" das crônicas de Machado de Assis também seriam apontadas por outros estudiosos. Sônia Brayner, por exemplo, em estudo pioneiro, afirma que o início do trabalho de cronista foi decisivo na elaboração de uma nova "atitude estética" do autor. Pautadas no princípio de "relativização textual", no contato cotidiano com o leitor historicamente datado, no trabalho sobre a oralidade, na fragmentação propositada e requerida, na estrutura ficcional dialógica, as crônicas teriam contribuído sobremaneira para a mudança progressiva que se opera na ficção machadiana. ${ }^{6}$ Também, ao indagar sobre a mudança que se opera no romance

\footnotetext{
${ }^{4}$ Cf. GRANJA, Lúcia. Domínio da boa prosa: narradores e leitores na obra do cronista. Cadernos de Literatura Brasileira, n. 23/24. São Paulo: Instituto Moreira Salles, 2008. p. 252-272; GRANJA, Lúcia. Um espaço de experimentação narrativa. Jornal da UNICAMP, n. 406, 25 a 31 ago. Campinas: 2008. p. $10-11$.

${ }^{5}$ ALENCAR, Mário. Advertência [reproduzida pela edição da Jackson de A Semana, em 1937]. In: ASSIS, Machado. A Semana. v. 1. Rio de Janeiro; São Paulo; Porto Alegre: W. M. Jackson Inc. Editores, 1955. p. 7. (Grifos meus.)

${ }^{6}$ BRAYNER, Sônia. As metamorfoses machadianas. In: Labirinto do espaço romanesco: tradição e renovação da literatura brasileira, 1880-1920. Rio de Janeiro: Civilização Brasileira, 1979. p. 51-118. Ver principalmente as páginas 55 a 65.
} 
machadiano a partir de 1880, com o início da publicação de Memórias póstumas de Brás Cubas, na Revista Brasileira, Marlyse Meyer chama a atenção para a presença de elementos estilísticos da crônica nos romances do escritor, mais especificamente o "tom leve, chistoso e descompromissado". ${ }^{7}$ Em estudos bastante rigorosos das crônicas de Machado de Assis, realizados a partir da década de 1980, John Gledson aponta, entre outras coisas, para o modo característico de tratar a história política do país bem como para o "diálogo tenso" do cronista com os leitores, traços estes que, segundo o estudioso, podem ser encontrados nos romances da maturidade do autor. ${ }^{8}$ Em artigo que aborda justamente o volume de crônicas de A Semana (1892-1893) organizado por John Gledson, Luiz Costa Lima retoma e desdobra as noções de "versatilidade do narrador e volubilidade", desenvolvidas por Roberto Schwarz, ${ }^{9}$ para o universo das crônicas de Machado de Assis:

Já nas crônicas, Machado reflete sagaz e cruelmente sobre a cena política e sobre as matrizes do pensamento "evoluído" [...] Muito mais que versátil ou volúvel [...] sua capoeira verbal provoca o desmantelo de certa lógica proposicional - a afirmação (a) gera (b) que gera (n), numa causalidade hilariante que pretende demonstrar o determinismo que domina as coisas - sem que, por aparecer também nas crônicas, se lhe possa interpretar como resultante de uma representação de personagens. [...] A "versatilidade do narrador" já seria em si uma fecundação por Machado do princípio de estilo que começara a exercitar na crônica. ${ }^{10}$

Há ainda trabalhos mais pontuais, como os de Sidney Chalhoub, que apontam, por exemplo, a temática da Abolição nas crônicas de Machado de Assis, mais especificamente na série "Bons dias!"; ${ }^{11}$ ou os de Alfredo Bosi, que procura sondar como Machado de Assis assiste ao "teatro político" de sua época, a partir da leitura de

\footnotetext{
${ }^{7}$ MEYER, Marlyse. Voláteis e versáteis: de variedades e folhetins se faz a crônica. In: As mil faces de um herói canalha. Rio de Janeiro: Editora da UFRJ, 1996. p.182.

${ }^{8}$ Cf. GLEDSON, John. Machado de Assis: ficção e história. Rio de Janeiro: Paz e Terra, 1986.

${ }^{9}$ Cf. SCHWARZ, Roberto. Um mestre na periferia do capitalismo: Machado de Assis. 4.ed. São Paulo: Duas Cidades; Ed. 34, 2000.

${ }^{10}$ LIMA, Luiz Costa. Machado: mestre de capoeira. In: Intervenções. São Paulo: Edusp, 2002. p. 333-334.

${ }^{11}$ CHALHOUB, Sidney. A abolição em crônicas. Jornal da UNICAMP, n. 406, 25 a 31 ago. Campinas: 2008. p. 5.
} 
sua produção jornalística. ${ }^{12}$ Através da referência a essas leituras é possível vislumbrar o caráter necessário e profícuo de estudos apurados das crônicas de Machado de Assis.

Várias foram as séries, publicadas em diversos jornais, ao longo de quase quarenta anos: "Comentários da semana" [Diário do Rio de Janeiro] (12/10/186105/05/1862); "Crônicas do Dr. Semana" [Semana Ilustrada] (08/12/1861-26/06/1864); "Crônicas" [O futuro] (15/09/1862-01/07/1863); "Ao acaso" [Diário do Rio de Janeiro] (12/07/1864-16/051865); "Cartas Fluminenses" [Diário do Rio de Janeiro] (05/03/1867 e 12/03/ 1867) "Badaladas" [Semana Ilustrada] (22/10/1871-01/07/1873); "História de quinze dias" [Ilustração Brasileira] (01/07/1876-01/01/1878); "História de trinta dias" [Ilustração Brasileira] (fevereiro 1878-março 1878); "Notas semanais" [O Cruzeiro] (02/06/1878-01/09/1878); "Balas de estalo" [Gazeta de Notícias] (02/07/188306/11/1885); "Gazeta de Holanda" [Gazeta de Notícias] (01/11/1886 - 24/02/1888); "A + B" [Gazeta de Notícias] (12/09/1886-24/10/1886); "Bons dias!" [Gazeta de Notícias] (05/04/1888-21/08/1897); "A semana" [Gazeta de Notícias] (24/041892-28/02/1897). ${ }^{13}$

Algumas crônicas apresentavam o nome Machado de Assis ou as iniciais M. A. ou M._de A., mas na maioria delas o autor lançou mão de nomes falsos. Diversos foram os pseudônimos com que o autor assinou seus textos: Gil, Job, Dr. Semana, Manassés, Eleazar, Lélio, João das Regras, Malvolio, Boas noites. Tal estratégia de uso de pseudônimos era amplamente utilizada pelos escritores e jornalistas do século XIX - na Gazeta de Notícias, por exemplo, entre 1877 e 1881, José do Patrocínio publicou suas crônicas com o pseudônimo de Proudhomme, enquanto Ferreira Araújo, proprietário do jornal, lançava mão da alcunha Lulu Sênior -, todavia, em Machado de Assis, a mesma estratégia de se escrever as crônicas na primeira pessoa do singular e assiná-las, em sua maioria, com um nome ficcional, será de fundamental importância para a construção da persona literária do escritor, pois o artifício cria um efeito de dissimulação que complexifica a construção do ponto de vista narrativo nessas produções, o que será aprimorado em sua ficção futura. Afinal, se o movimento inicial, no trato com as crônicas, é atribuir a Machado de Assis as opiniões, os julgamentos, o posicionamento

\footnotetext{
${ }^{12}$ BOSI, Alfredo. O teatro político nas crônicas de Machado de Assis. Revista Brasileira, n.41. Rio de Janeiro: Academia Brasileira de Letras, 2004. p. 37-76.

${ }^{13}$ As crônicas publicadas em 1959, no periódico $O$ espelho, não comportam uma série propriamente dita: as primeiras delas aparecem sob o nome de "Aquarelas" (11/09/1859-30/10/1859); e as outras são: "Os imortais" (18/09/1859), "O marinheiro batavo" (25/09/1859) e "A reforma pelo jornal" (23/101859).
} 
político e ideológico manifestos na sua produção jornalística, o uso dessas máscaras propõe outro movimento, que é o de atentar para a relação de diferença, e não de pura semelhança, que se estabelece entre o autor real e o narrador fictício. ${ }^{14}$

Se, diante dessa vasta e incessante produção, a tentação é voltar-se para todo o conjunto das crônicas machadianas, o objetivo desta reflexão não é esse. Parte-se das séries "História de quinze dias" e "Histórias de trinta dias" para examinar o olhar singular do narrador dessas crônicas sobre o assunto internacional mais premente na época, a "questão do Oriente". Tal olhar transcende a dicção jornalística tradicionalmente constituída e materializa-se no limite tênue entre a ficção e a história.

Publicadas desde o primeiro número do periódico Illustração Brasileira, criado pelos irmãos Carlos e Henrique Fleiuss, as crônicas, iniciadas em junho de 1876 e encerradas em março de 1878, formam um todo de quarenta, sempre apresentadas sob o pseudônimo de Manassés. A mudança de nome da série - de "História de quinze dias" para "História de trinta dias"15 - deveu-se simplesmente ao fato de a revista entrar em crise e mudar a sua periodicidade, porém a estrutura e o estilo das crônicas não sofreram alteração com a mudança. ${ }^{16}$

Antes de aparecer na Illustração Brasileira, o pseudônimo Manassés fora usado por Machado de Assis no efêmero periódico A Época, em duas ocasiões, ambas em fins de 1875, em que apareceram os contos "A chinela turca" (14/11/1875) e "O sainete" (01/12/1875). O nome Manassés, de origem hebraica, carrega uma ambiguidade. Ao mesmo tempo em que é homônimo do patriarca judeu, primogênito de José, que deu seu nome a uma das tribos de Israel, "Manassés" ("Menashe") deriva da palavra "esquecer" - literalmente, "saltar para cima e para longe" -, sugere o poder de

\footnotetext{
${ }^{14}$ Sobre a questão da construção do ponto de vista narrativo nas crônicas de Machado de Assis, ver: PEREIRA, Leonardo Affonso de Miranda. O carnaval das letras: literatura e folia no Rio de Janeiro do século XIX. Campinas: Editora da Unicamp, 2004; CANO, Jefferson et al. Narradores do ocaso da monarquia (Machado de Assis, cronista). Revista Brasileira, n. 55. Rio de Janeiro: Academia Brasileira de Letras, 2008. p. 289-316.

${ }^{15}$ Utiliza-se aqui a edição de 1957 da W. M. Jackson Inc., cotejada com a edição mais recente, organizada por Leonardo Affonso de Miranda Pereira: ASSIS, Machado de. Crônicas. v. 3. Rio de Janeiro; São Paulo; Porto Alegre: W. M. Jackson Inc. editores, 1957. p. 77-326; ASSIS, Machado. História de quinze dias. Organização de Leonardo Affonso de Miranda Pereira. Campinas: Editora da Unicamp, 2009.

${ }^{16}$ Quantos às informações a respeito da série, ver: CANO, Jefferson et al. Narradores do ocaso da monarquia (Machado de Assis, cronista). Revista Brasileira, n. 55, cit., p. 296-301.
} 
nos fazer esquecer as provações, dificuldades e tribulações deste mundo. ${ }^{17} \mathrm{Ou}$ seja, o cronista da quinzena, que aparentemente deveria trazer à tona os acontecimentos, é também aquele que nos faz esquecer, que produz o esquecimento. O jogo de sentidos aponta para o caráter dialógico e polifônico que impera nessas crônicas e não se restringe apenas ao nome ficcional do autor dos textos.

Também o título da série traz uma ambivalência, pois, se, por um lado, o termo "história" aponta para uma definição antiga de crônica, aquela que se refere aos cronistas dos séculos XV e XVI, cujos textos encaminham-se para o que convencionouse chamar de "escrita da história", ${ }^{18}$ por outro, os sintagmas "de quinze dias" e "de trinta dias" desconstroem o tom elevado do primeiro termo, pois apontam para o caráter ligeiro dos comentários, produzidos "ao correr da pena", ao calor da hora. Em crônica do dia 15 de março de 1877, o próprio Manassés reflete sobre o seu estatuto de cronista:

Mais dia menos dia, demito-me deste lugar. Um historiador de quinzena, que passa os dias no fundo de um gabinete escuro e solitário, que não vai às touradas, às câmaras, à rua do Ouvidor, um historiador assim é um puro contador de histórias.

E repare o leitor como a língua portuguesa é engenhosa. Um contador de histórias é justamente o contrário de historiador, não sendo um historiador, afinal de contas, mais do que um contador de histórias. Por que essa diferença? Simples, leitor, nada mais simples. O historiador foi inventado por ti, homem culto, letrado, humanista; o contador de histórias foi inventado pelo povo, que nunca leu Tito Lívio, e entende que contar o que se passou é só fantasiar. ${ }^{19}$

Conforme salientam, em trabalho conjunto, Jefferson Cano, Sidney Chalhoub, Leonardo Affonso de Miranda Pereira e Ana Flávia Cernic Ramos, ao apontarem a dificuldade de Manassés em definir o seu próprio papel, "Machado de Assis ironizava a pretensão do título da série e do projeto editorial no qual aparecia, a Illustração

\footnotetext{
${ }^{17}$ Cf. BEIT CHABAD. Calendário judaico. Disponível em: <http://www.chabad.org.br/datas/calendario/ cheshvan.html>; acesso em: 29 de setembro de 2008.

${ }^{18}$ Sobre a construção do discurso da história através das antigas crônicas de João de Barros, Diogo do Couto e Fernão Mendes Pinto, ver: LIMA, Luiz Costa. O redemunho do horror: as margens do Ocidente. São Paulo: Planeta, 2003. p. 25-135.
}

${ }^{19}$ ASSIS, Machado de. Crônicas. v. 3., cit., p. 199. 
Brasileira".$^{20}$ A pretensão dos irmãos Fleiuss era produzir um periódico bem cuidado, capaz de rivalizar com aqueles editados no exterior, e tal esmero significava: impressão luxuosa, elevação moral, valorização da nacionalidade, aura de imparcialidade, isenção partidária. Com a pena da galhofa, Manassés vira do avesso as perspectivas do periódico, ao assumir-se com um "puro contador de histórias".

$\mathrm{Na}$ mesma crônica, ao conversar com um amigo, ainda a respeito de sua aversão às touradas, justificando o seu direito de falar sobre elas, mesmo não indo vêlas, Manassés completa: "[...] não preciso ver a guerra para detestá-la". É justamente esse o tema que interessa aqui: a posição de Manassés em relação à guerra, em especial os conflitos que naquele momento ocorrem nos Bálcãs, ligados ao desmembramento do Império Otomano e à formação do estado sucessor, a República da Turquia. Situemonos. Na historiografia clássica, a expressão "questão do Oriente" relaciona-se com a decadência do Império Otomano, denominado "o homem doente da Europa" pelo czar russo Nicolau I nas vésperas da guerra da Crimeia (1853-1856), que opôs os russos a uma coalizão formada pela Turquia e os aliados Inglaterra, França e Piemonte.

Valelembrar aqui que essa guerra aparece em alguns capítulos do romance Dom Casmurro (1899). No capítulo LXXXIV ("Chamado"), ${ }^{21}$ quando Bentinho volta da casa de Sancha, onde reencontrara Capitu, seus devaneios relacionados ao encontro com a amiga são interrompidos por um chamado do dono da loja de louça, que comunica a morte de filho, Manduca. Depois de alguns capítulos em que narra a visão horrenda do defunto e a sua estratégia de acompanhar o enterro apenas para não ir ao seminário e, assim, reencontrar Capitu, Bentinho, no capítulo XC ("A polêmica"), ${ }^{22}$ narra a polêmica que travara com Manduca a respeito da guerra da Crimeia, "que então ardia e andava nos jornais". Manduca sofria de lepra e passava a maior parte do tempo dentro do quarto. A contenda travada com Bentinho acaba lhe trazendo, segundo a voz narrativa, algum alívio. Os dois passam meses trocando argumentações por escrito, nas quais Bentinho defende a "razão dos russos" e Manduca, "a justiça dos aliados à

\footnotetext{
${ }^{20}$ CANO, Jefferson et al. Narradores do ocaso da monarquia (Machado de Assis, cronista). Revista Brasileira, n. 55, cit., p. 298.

${ }^{21}$ ASSIS, Machado. Dom Casmurro. In: 890-891. Obra completa. v. 1. Rio de Janeiro: Aguilar, 1959. p.

${ }^{22}$ Idem, p. 894-896.
} 
Turquia"; ao longo do capítulo tem-se a repetição do estribilho que sempre encerra as inventivas de Manduca: "Os russos não hão de entrar em Constantinopla!" Ao final do capítulo, o narrador reflete sobre a "predição eterna" de Manduca e associa a dissolução do rapaz à possível dissolução do Estado turco. De certa maneira, o mesmo estribilho de Manduca ressoa nas crônicas de Manassés, este também lamenta ao longo de seus textos a iminente queda da Sublime Porta. ${ }^{23}$

Em crônica datada de fevereiro de 1878, a primeira com o nome de "História de trinta dias" 24 e a última da série em que o tema da questão do Oriente aparece, depois de tratar da mudança do nome, da possível dissolução da Câmara e das chuvas no Ceará, Manassés afirma:

Caiu enfim a Turquia, foi vencida pelo urso do norte, fato que parece alegrar a meio mundo, ainda não sei por quê.

- Por quê? Porque são infiéis - dizia-me há dias um vizinho que não põe os pés na igreja.

Qualquer que seja a culpa, a verdade é que vamos ter a paz de Europa; e parece que dentro de pouco tempo os turcos estarão na Ásia.

Constantinopla deixará de ser a última cidade pitoresca da Europa. O formalismo ocidental (porque São Petersburgo é uma Londres ou uma Paris mais fria) vai ali estabelecer seus arraiais. Adeus, cafés muçulmanos, adeus, cafetãs, narguilés, adeus ausência de municipalidade, cães soltos, ruas mal calçadas, mas pisadas pelo pé indolente da otomana; adeus! Virá o alinhamento, a botina parisiense, a calça estreita e ridícula, o fraque, o chapéu redondo, toda a nossa miséria estética.

Ao menos, Constantinopla, resista alguns anos até que eu te possa ver, e ir respirar as brisas do Bósforo, ouvir um verso do Alcorão e ver dois olhos saindo dentre o véu das tuas belas filhas. Faz-me este obséquio, Constantinopla! ${ }^{25}$

Manassés lamenta, meio irônico e meio nostálgico, a troca dos velhos costumes otomanos pelo "alinhamento" ocidental. O mesmo tom é o que abre a série, em $1^{\circ}$ de

\footnotetext{
${ }^{23}$ As crônicas da série "História de quinze dias" / "História de trinta dias" em que Machado de Assis faz alguma referência à questão do Oriente são as seguintes: 01de julho de 1876; 01 de agosto de 1876; 15 de agosto de 1876; 01 de setembro de 1876; 15 de setembro de 1876; 01 de outubro de 1876; 15 de janeiro de 1877; 01 de fevereiro de 1877; 15 de fevereiro de 1877; 01 de maio de 1877; 15 de maio de 1877; 01 de setembro de 1877; 15 de outubro de 1877; fevereiro de 1878 .

${ }^{24}$ ASSIS, Machado de. Crônicas. v. 3, cit., p. 313-319. A série só teria mais um exemplar, o de março de 1878.

${ }^{25}$ Idem, p. 315-316.
} 
julho de 1876: "Dou começo à crônica no momento em que o Oriente se esboroa e a poesia parece expirar às mãos grossas do vulgacho. Pobre Oriente! Mísera poesia!"26 Manassés refere-se à deposição e ao assassinato do sultão otomano Abdul-Aziz e parece comentar o que a imprensa europeia da época anunciava, ou seja, a ascensão do liberalismo dos reformadores turcos. Em seguida, narra o encontro do ex-padixá com dois anjos negros de olhos azuis, citados no Alcorão, e com o profeta, que termina em um pontapé que joga Abdul-Aziz de volta para a terra. Nas palavras do profeta: "A Turquia vai ter uma câmara, um ministério responsável, uma eleição, uma tribuna, interpelações, crises, orçamentos, discussões, a lepra toda do parlamentarismo e do constitucionalismo. Ah, quem dera Omar! Ah! Quem me dera Omar!"27 O narrador também se declara inconformado com tal situação e afirma que a beleza da tradição - a poesia - sucumbe ante as mudanças ideológicas: "Mas o que eu apuro de tudo o que nos vem pelo cabo submarino e vapores transatlânticos é que o Oriente acabou e com ele a poesia." Em um tom visivelmente exagerado, Manassés chora a abolição do serralho, com seu harém de belas mulheres e eunucos, e conclui: "Tudo isso é poesia que o vento do parlamentarismo dissolveu em um minuto de cólera e num acesso de eloquência". ${ }^{28}$ Através de um argumento elitista e excludente, o narrador insere em uma mesma série a poesia, a originalidade do mundo árabe, os eunucos e o harém de belas mulheres. Com esse artifício, Machado de Assis desvela, de maneira irônica, a violência de um mundo do qual Manassés se mostrava nostálgico e, aparentemente, incapaz de relacionar com a escravidão e a dependência comuns ao Ocidente. Nas palavras de Leonardo Affonso de Miranda Pereira, Machado de Assis "evidenciava, dessa forma, o sentido dos esquecimentos do narrador: ao limitar-se a lamentar a força poética (ou ideológica) desse mundo que se perdia, deixava explicitamente de lado o ponto de vista das vítimas desse processo". ${ }^{29}$

Na crônica de $1^{\circ}$ de agosto de 1876 , Manassés volta ao tema da "constituição turca" e, boquiaberto diante do artigo primeiro da dita constituição, que reconhece,

\footnotetext{
${ }^{26}$ Idem, p. 77.

${ }^{27}$ Idem, p. 79.

${ }^{28}$ Idem, p. 80.

${ }^{29}$ PEREIRA, Leonardo Affonso de Miranda. Introdução. In: ASSIS, Machado de. História de quinze dias. Organização de Leonardo Affonso de Miranda Pereira. Campinas: Editora da Unicamp, 2009. p.24
} 
protege e subvenciona todos os cultos, afirma: "Eu palpo-me, esfrego os olhos, dou murros no peito e na cabeça, agito os braços, passeio de um lado para outro, a fim de certificar-me que não estou sonhando. O Alcorão subvencionando o Evangelho! [...] Se isto não é o fim do mundo, é pelo menos o penúltimo capítulo. Que abismo entre Omar e Mourad V!"30

Outros comentários referentes à questão do Oriente aparecem nas crônicas de $1^{\circ}$ e 15 de setembro de 1876 . Na primeira, o autor fala mais uma vez dos problemas na Turquia, dessa vez anunciado o fracasso do projeto de constituição:

[...] Assim, a Turquia está em risco de perder seu atual sultão, ou o sultão, de perder a Turquia. Há pouco mais de um mês governava o tio deste; este cede o passo a um irmão. É uma peça mágica com música e pancadaria. A Turquia está a macaquear a Bolívia de um modo escandaloso: muda de sultões como a Bolívia, de presidentes e o leitor, de camisas. ${ }^{31}$

Na crônica seguinte, o narrador compara um "rolo no largo de São Francisco", acontecido no dia 08 de setembro e noticiado nos jornais da época, com a revolta sérvia contra o domínio otomano, mais uma vez a questão do Oriente na ordem do dia:

O referido rolo, verdadeiro hors-d'oeuvre na festa, foi uma representação da guerra do Oriente.

Os urbanos fizeram de sérvios e os imperiais marinheiros, de turcos.

A estação do largo foi a Belgrado.

Assim distribuídos os papéis, começou a pancadaria, que acabou por deixar 19 homens fora de combate.

Não tendo havido ensaio, foi a representação excelente pela precisão dos movimentos, naturalidade do alvoroço, e verossimilhança dos ferimentos.

Só numa coisa a reprodução não foi perfeita: é que os telegramas da Belgrado de cá confessam as perdas, coisa que os da Belgrado de lá nem à mão de Deus Padre querem confessar. ${ }^{32}$

\footnotetext{
${ }^{30}$ ASSIS, Machado de. Crônicas. v. 3, cit., p. 99-100.

${ }^{31}$ Idem, p.110-111.

${ }^{32}$ Idem, p. 122.
} 
A mudança de poder na Turquia e a revolta da Sérvia pela independência, que seria reconhecida em 1878, servem de mote para que apareça a noção de guerra como espetáculo, "peça mágica com música e pancadaria". Tomando o libreto da guerra de lá e transportando-o para o "rolo" de cá, Manassés, com humor e ironia, cruza o largo de São Francisco com Belgrado em uma espécie de sainete, que adianta a máxima que aparecerá na crônica seguinte, de $1^{\circ}$ de outubro de 1876 , de que a guerra é uma ópera:

Conheço um homem que anda meio desconfiado de que não há guerra da Sérvia nem império turco; consequentemente, que não há sultões caídos, nem suicidados. Mas que são as notícias com que os paquetes vêm perturbar nossas digestões? Diz ele que é uma ópera de Wagner e que os jornais desta corte traduzem mal as notícias que acham nos estrangeiros.

A ópera, segundo este meu amigo, intitula-se Os três Sultões ou o Sonho do grão-vizir, música de Wagner e libreto de Gortchakoff. Tem numerosos quadros. A introdução no estilo herzegoviano é um primor, conquanto fosse ouvida sem grande atenção por parte do público. A atenção começou quando rompeu o dueto entre Milano e Abdul-Aziz, e depois o coro do softas, que derrocam Abdul... O mais sabemos todos.

A este meu amigo, replico eu dizendo que a coisa não é ópera, mas guerra; sendo a prova disso o telegrama há dias publicado, que trouxe a notícia do achar-se em começo a paz. Respondeu-me que é ilusão minha. "Há decerto um coro que entra cantando: Pace, pace, mas é um coro. Que queres tu? Antigamente as óperas eram música, hoje são isso e muita coisa mais. Vê os Huguenotes, com a descarga de tiros no fim. Pois é a mesma coisa a nova composição de Wagner. Há tiros, batalhões, mulheres estripadas, crianças partidas ao meio, aldeias reduzidas a cinzas, mas é tudo ópera. ${ }^{133^{3}}$

Como não lembrar Marcolini, o velho tenor decadente e "já sem voz", que aparece no capítulo IX ("A ópera") de Dom Casmurro, para afirmar:

- A vida é uma ópera e uma grande ópera. O tenor e o barítono lutam pelo soprano, em presença do baixo e dos comprimários, quando não são o soprano e o contralto que lutam pelo tenor, em presença do mesmo baixo e dos mesmos comprimários. Há coros numerosos, muitos bailados, e a orquestração é excelente... ${ }^{34}$

\footnotetext{
${ }^{33}$ Idem, p. 130-131.

${ }^{34}$ ASSIS, Machado. Dom Casmurro. In: Obra completa. v. 1, cit., p. 815.
} 
Na cosmogonia de Marcolini, Deus é o poeta que escreveu um libreto de ópera, do qual abre mão, por entender que tal criação não é própria de sua eternidade. Satanás é o jovem músico de grande futuro, mas que, ao tramar uma rebelião, é expulso do conservatório do céu. Ao sair, Satanás leva consigo, para o inferno, o manuscrito abandonado, que será encenado em nosso planeta. Já na ópera que é a guerra, nas palavras do amigo de Manassés, o papel de Deus, libretista, é ocupado pelo russo Gortchakov, então ministro dos Negócios Estrangeiros, e que teve papel premente na reorganização do país depois da guerra da Crimeia; e Satanás é ninguém menos que o compositor alemão Richard Wagner, o tema é a guerra, com toda a virulência e crueldade que lhe são peculiares. É interessante a nacionalidade dos dois "personagens", russa e alemã, relativas ao maior oponente da Turquia e ao país que se tornaria o seu principal aliado.

Por trás das falas de Marcolini, em Dom Casmurro, e do amigo de Manassés, na crônica, ressoa a ironia machadiana, que traz um interessante aspecto do discurso operístico: a possibilidade de transformação do cotidiano em espetáculo, o momento em que realidade e ficção unem-se, eliminando a distinção entre espectador e espetáculo. Através do espetáculo ("a ópera") em diálogo com o dado real ("a guerra entre sérvios e turcos"), Machado de Assis recria e reapresenta a realidade como ficção alegórica.

No estudo "Machado Maxixe: o caso Pestana", José Miguel Wisnik afirma que a crônica é a polca da literatura:

[...] o mundo em que proliferam as polcas, serelepe e livremente associativo, capaz de incorporar qualquer matéria à sua lógica vivaz, tocando alegre e irresponsavelmente no nervo agudo e fortuito das coisas, corresponde, de certa forma, ao próprio universo da crônica, no qual o escritor se permite borboletar entre as notícias internacionais e um novo remédio para os calos, entre uma grave pendenga eleitoral, um incidente na rua do Ouvidor, uma frase ouvida no bonde ou a paz nos cemitérios $[\ldots]^{35}$

Ampliando afirmação de José Miguel Wisnik, pode-se dizer ainda que também a ópera, por sua natureza híbrida e polifônica, na qual uma multiplicidade de vozes

35 WISNIK, José Miguel. Machado Maxixe: o caso Pestana. In: Sem receita. São Paulo: Publifolha, 2004. p. 39 
ressoa, é um discurso interessante para se aproximar das crônicas de Machado, também com seu constante dialogismo, com sua interseção de linguagens, imagens, vozes e espaços. Através de movimentos bem engendrados, o autor mistura com a temática do esboroar do Império Otomano reflexões sobre o Corão, o calçamento da rua das Laranjeiras, notícias das eleições, a crise do boi, notas sobre a cena lírica carioca, o surgimento de mulheres santas no Nordeste, enfim, produzindo a coadunação do "fato extraordinário" com o dito ordinário. Como se pode perceber, aqui, através da leitura de algumas das crônicas do autor, essa relativização proposta pelo discurso machadiano é conduzida com cabal crueldade e ao mesmo tempo assumindo a face do humor, criando um estranhamento e distanciamento sistemático do discurso em relação aos fatos comentados. Outra questão interessante esboçada através das referências a Dom Casmurro - e, por que não, do uso do pseudônimo Manassés também para a assinatura dos contos - é a relação estrutural e temática que se pode estabelecer entre as crônicas e o restante da obra do autor.

Por fim, gostaria de citar a primeira parte da crônica de fevereiro de 1878, em que Manassés fala da mudança de periodicidade do texto, de quinze para trinta dias. $\mathrm{O}$ narrador manifesta a preocupação com a mudança, pois, segundo ele, quinze dias é um período cujos limites são visíveis, mas trinta dias é "quase uma eternidade". "Um fato de trinta pertence à história, não à crônica", afirma Manassés, e continua: "Digo isto, leitor amigo, para que, se alguma vez esta crônica te parecer mofada, fiques sabendo que a culpa não é minha, mas do tempo - esse velho e barbudo Cronos, que a tudo lança o seu manto de gelo".

Por traz da reflexão de Manassés, desconfiado do rápido envelhecimento das novidades, Machado de Assis demonstra por que aplica às coisas o travo dociamaro da ironia, que delas tira um permanente fulgor. Talvez nisso resida o prazer e o gosto de aventura proporcionado, ainda, na leitura e nos diálogo com esses textos. 
Referências:

ALENCAR, Mário. Advertência [reproduzida pela edição da Jackson de A Semana, em 1937]. In: ASSIS, Machado. A Semana. v. 1. Rio de Janeiro; São Paulo; Porto Alegre: W. M. Jackson Inc. Editores, 1955.

ASSIS, Machado de. Crônicas. v. 3. Rio de Janeiro; São Paulo; Porto Alegre: W. M. Jackson Inc. editores, 1957.

História de quinze dias. Organização de Leonardo Affonso de Miranda Pereira. Campinas: Editora da Unicamp, 2009.

BEIT CHABAD. Calendário judaico. Disponível em: <http://www.chabad.org.br/datas/calendario/ cheshvan.html>; acesso em: 29 de setembro de 2008.

BOSI, Alfredo. O teatro político nas crônicas de Machado de Assis. Revista Brasileira, n.41. Rio de Janeiro: Academia Brasileira de Letras, 2004.

BRAYNER, Sônia. As metamorfoses machadianas. In: Labirinto do espaço romanesco: tradição e renovação da literatura brasileira, 1880-1920. Rio de Janeiro: Civilização Brasileira, 1979.

CANDIDO, Antonio. A vida ao rés-do-chão. In: Recortes. São Paulo: Companhia das Letras, 1993.

CANO, Jefferson et al. Narradores do ocaso da monarquia (Machado de Assis, cronista). Revista Brasileira, n. 55. Rio de Janeiro: Academia Brasileira de Letras, 2008.

CHALHOUB, Sidney. A abolição em crônicas. Jornal da UNICAMP, n. 406, 25 a 31 ago. Campinas: 2008.

GLEDSON, John. A história contada em detalhes (Entrevista a Álvaro Kassab). Jornal da UNICAMP, n. 406, 25 a 31 ago. Campinas: 2008.

Machado de Assis: ficção e história. Rio de Janeiro: Paz e Terra, 1986.

GRANJA, Lúcia. Domínio da boa prosa: narradores e leitores na obra do cronista. Cadernos de Literatura Brasileira, n. 23/24. São Paulo: Instituto Moreira Salles, 2008.

. Um espaço de experimentação narrativa. Jornal da UNICAMP, n. 406, 25 a 31 ago. Campinas: 2008.

LIMA, Luiz Costa. Machado: mestre de capoeira. In: Intervenções. São Paulo: Edusp, 2002.

O redemunho do horror: as margens do Ocidente. São Paulo: Planeta, 2003. 
MEYER, Marlyse. Voláteis e versáteis: de variedades e folhetins se faz a crônica. In: As mil faces de um herói canalha. Rio de Janeiro: Editora da UFRJ, 1996.

PEREIRA, Leonardo Affonso de Miranda. Introdução. In: ASSIS, Machado de. História de quinze dias. Organização de Leonardo Affonso de Miranda Pereira. Campinas: Editora da Unicamp, 2009.

O carnaval das letras: literatura e folia no Rio de Janeiro do século XIX.

Campinas: Editora da Unicamp, 2004.

SCHWARZ, Roberto. Um mestre na periferia do capitalismo: Machado de Assis. 4.ed. São Paulo: Duas Cidades; Ed. 34, 2000.

WISNIK, José Miguel. Machado Maxixe: o caso Pestana. In: Sem receita. São Paulo: Publifolha, 2004.

Leonardo Francisco Soares é doutor em Letras: Estudos Literários, pela Universidade Federal de Minas Gerais. Atua como professor adjunto do Instituto de Letras e Linguística da Universidade Federal de Uberlândia. É professor permanente do Programa de Pós-Graduação em Letras da mesma universidade. Publicou o ensaio "A batalha de Kosovo Polje na literatura de Ismail Kadaré, ou quem reivindica a verdade histórica?" no livro Literatura e guerra (UFMG, 2010). Tem artigos publicados em diversos periódicos do país, tais como: Aletria (UFMG); Cadernos de Língua e Literatura Hebraica (USP), Literatura e Autoritarismo (UFSM); Letras \& Letras (UFU); Caligrama (UFMG). E-mail: <leofs@ileel.ufu.br>

Recebido: 10/03/2012

Aprovado: 15/05/2012 